\title{
COMPARATIVE CONTENT ANALYSIS OF THE WEBSITES OF GASTRONOMY CITIES REWARDED BY UNESCO CREATIVE CITIES NETWORK
}

\author{
Sedat BÜTÜN* \\ Dumlupinar University, Kütahya Vocational School of Social Sciences, \\ Tourism and Travel Services Kütahya, Turkey, e-mail: sedat.butun@dpu.edu.tr \\ Sibel ÖNÇEL \\ Anadolu University, Faculty of Tourism, \\ 26470 Eskisehir, Turkey, e-mail: sguler@anadolu.edu.tr
}

\begin{abstract}
Citation: Bütün, S., \& Önçel, S. (2019). COMPARATIVE CONTENT ANALYSIS OF THE WEBSITES OF GASTRONOMY CITIES REWARDED BY UNESCO CREATIVE CITIES NETWORK. GeoJournal of Tourism and Geosites, 26(3), 831-848. https://doi.org/10.30892/gtg.26313-401
\end{abstract}

\begin{abstract}
This study aims to evaluate the written and visual materials in the web sites of 26 cities that joined the Creative Cities Network under the category of gastronomy. Comparative content analysis was used for the purpose of the study to evaluate the official websites of gastronomy-themed cities. The websites of the cities were examined in terms of design, functionality, communication and interaction features, destination promotion and gastronomy promotion. The findings revealed that gastronomy cities, which accept creativity as a strategic factor in economic social and cultural sustainable development missions, do not have convenient and adequate contents. Further the results showed that the websites of these cities were insufficient in terms of design and functionality. It was also found that the promotion of the destinations was inadequate compared to gastronomical values. Conclusions were drawn on the basis of findings.
\end{abstract}

Key words: UNESCO, creative cities network, gastronomy city, destination promotion, web content analysis

\section{INTRODUCTION}

The industries related to creativity make significant contributions to social and cultural developments of the cities and countries. These industries, which are based on individual creativity, skills, and competence, and which have the potential to generate income and employment through production or use of intellectual property, are at the core of cultural and economic strategies on local and regional scale (DCMS 2000; Taylor, 2006). Although there is no consensus in literature regarding the limits of creative

\footnotetext{
* Corresponding author
} 
industries or areas (Bakhshi et al., 2013; CCS, 2013; Hartley, 2005; Hesmondhalgh, 2002), it is observed that the industries that produce genuine goods and services with imagination and innovative ideas are associated with creativity (UNCTAD, 2008). Unlike all other classifications regarding creative industries, gastronomy was regarded as a field of creativity for the first time within the scope of UNESCO's Creative Cities Network and cities with authentic gastronomy traditions were rewarded as "Creative City of Gastronomy”. Considered as a cultural heritage, the tradition of gastronomy provides significant opportunities to cities in terms of international recognition and enhancing destination's image. Gastronomy is also effective on tourists' travel motivations and has direct or indirect influence on their travel decisions. In this sense, as a type of alternative tourism, gastronomy provides great opportunities to cities. Because of the international structure and severe competition in tourism sector, the destinations should promote themselves in the international arena in the most effective way possible. At this point, internet and websites become the most suitable platforms for promotion. Internet is one of the most commonly used sources of information throughout the world, and it is one of the most significant sources that people use to obtain information regarding the destinations before traveling. Thus, the internet may be considered a significant source for promotion and marketing activities that are necessary for cities with gastronomy tradition to use gastronomy as a tool of their economic, social and cultural development.

In parallel with the increasing importance of the internet and websites, the number of studies regarding website contents has also increased. The first study in tourism literature regarding the assessment of websites was conducted by Murphy et al. (1996). It is observed that the number of subsequent website assessments with different measurements and approaches has also increased. The studies in literature are mostly about evaluation of hotels, travel agencies, destination marketers and travel websites (Schmidt et al., 2008; Ip et al., 2012; Escobar-Rodríguez \& Carvajal-Trujillo, 2013; Ting et al., 2013; Leung et al., 2016; Salem \& Čavlek, 2016; Atıf, 2018; Bayram \& Yayll, 2009; Choi et al., 2007; Kim et al., 2009; Chiou et al., 2011). However, the websites of gastronomy cities have not been examined yet. Therefore, this study aims to evaluate the written and visual materials in the web sites of cities entitled with 'Creative City of Gastronomy' award listed in the Creative Cities Network under the category of gastronomy. In these websites, especially the creativity and gastronomy identity of the destination is promoted. The results of the study has the potential to make suggestions regarding to what extent the gastronomy cities use their websites effectively.

\section{LITERATURE REVIEW}

\section{The Concept of Creative Industries}

The concept of creativity, which is characterized in various ways, can be defined as the ability to show up with innovative, remarkable, and valuable ideas and works (Boden, 2009). The term "creativity" is related to authenticity, imagination, novelty, inspiration, and invention capability. It refers to new ideas and the use of these ideas for production of genuine artistic-cultural products, functional creations, scientific inventions, and technological innovations (UNCTAD, 2008). Although creativity may take place in production processes and products of tourism or any other industry, this would not make the entire industry as a creative industry. According to the generally accepted definition of the Department of Digital, Culture, Media \& Sport (DCMS) in United Kingdom, the creative industries are defined as "those industries, which have their origin in individual creativity, skill and talent and which have a potential for wealth and job creation through the generation and exploitation of intellectual property" (DCMS, 2001; CCS, 
2013). On the other hand, United Nations Conference on Trade and Development (UNCTAD) has defined the creative industries in a series of reports on creative industries published in 2008 and 2010. Accordingly, the creative industries are the industries (1) where creativity and intellectual capital are used as primary inputs in creation, production and distribution of goods and services; (2) which include a set of knowledgebased activities that focus on generating income not only through arts, but also through trade and intellection property rights; (3) which comprise tangible goods with creative content, economic value, and market objectives, and intangible intellectual or artistic services; (4) which are positioned at the intersection point of the artisans, services and industrial sectors; and (5) which create a new dynamic sector in global trade (Boix et al., 2011; Marinova \& Borza, 2013). There are problems and discussions regarding the definition of creative industries (CCS, 2013) and it is very difficult to distinguish them from other industries due to their close economic relations with each other. Nevertheless, it is observed that some classifications are used to materialize the definition and scope of creative industries. The models suggested for classification of creative industries are not considered completely wrong or right. These models should be regarded as different ways of interpreting the characteristics of creative production (UNCTAD, 2008).

According to the model in Creative Industries Mapping Document published by DCMS in 1998 (cited by Roodhouse 2006), the creative industries include 13 creative sectors: advertising, architecture, arts and antiques markets, crafts, design, designer fashion, film and video, interactive leisure software, music, performing arts, publishing, software and computer services, television and radio (DCMS, 2001; CCS, 2013).

Table 1. DCMS and UNESCO's Classification regarding Fields/Industries of Creativity (Data source: DCMS Creative Industries Mapping Document and Creative Cities Network Catalog.)

\begin{tabular}{|c|c|}
\hline Creative Industries according to DCMS & Creative Industries according to UNESCO \\
\hline Advertising & Crafts and folk arts \\
\hline Architecture & Design \\
\hline Arts and antiques market & Film \\
\hline Crafts & Literature \\
\hline Design & Music \\
\hline Designer fashion & Media arts \\
\hline Film and video & \\
\hline Interactive leisure software & \\
\hline Music & \\
\hline Performing arts & \\
\hline Publishing & \\
\hline Software and computer services & \\
\hline Television and radio & \\
\hline
\end{tabular}

Together with UNESCO Creative Cities Network, a new classification has entered into the literature for creative industries in 2004. Although UNESCO's creative industry concept shares similarities with DCMS's creative industries model, UNESCO has included the theme of gastronomy in its creative industries model and that is what distinguishes it from similar classifications. There are seven creative industries in UNESCO's model. These are: crafts and folk arts, design, film, media arts, literature, music, and gastronomy (https://en.unesco.org/creative-cities/content/about-us).

\section{UNESCO Creative Cities Network and Gastronomy Cities}

UNESCO Creative Cities Network (UCCN) was created in 2004 in order to encourage cooperation among cities, which consider (define) creativity as a strategic 
factor for their sustainable urban development (https://en.unesco.org/creativecities/content/about-us). Cooperation and sharing knowledge and experiences are critical for using creativity as a leverage in the process of urban development. In this sense, UNESCO's Creative Cities Network offers unparalleled opportunities to the cities. This program offers opportunities for peer learning processes and collaborative projects in order to fully capitalize their creative assets and use this as a basis for building sustainable inclusive, and balanced development in economic cultural and social terms (https://en.unesco.org/creative-cities/content/why-creativity-why-cities).

The cities that accept undertakings, such as supporting creativity and culture industries, collaborating with the other cities within the network and developing cooperation, stimulating participation in cultural life and integrating culture into urban development plans can join these networks. By joining the Creative Cities Network, the cities aim the following in general: (1) to promote their cultural assets in the international area, (2) to turn creativity into one of the main factors of local economic and social development, (3) to mutually share knowledge with other similar cities, (4) to improve their local capacities, and (5) to improve innovation and creativity through exchange of knowledge, experience, and technological know-how (https://en. unesco.org/creative-cities/content/why-creativity-why-cities). UNESCO Creative Cities Network includes seven creative fields as Crafts and Folk Arts, Design, Film, Gastronomy, Literature, Media Arts, and Music. There are 180 cities from 72 countries within the network that comprises these seven fields of creativity (Creative Cities Network Catologue, 2018; https://en. unesco.org/creative-cities/creative-cities-map).

The cities, which are considered critical forces behind the economy, have both physical and nonphysical cultural assets. Since it has nonphysical features, gastronomy as a cultural asset has been included within the Creative Cities Network by UNESCO as one of the creative industries that is a determinant of urban economic development. Since it has local characteristics, and it indicates a unique and rich tradition that is shaped according to the geographical, natural, historical, and climatic conditions of the cities, gastronomy is regarded as a significant field of creativity for cities. Upon acceptance of gastronomy among UNESCO Creative Cities Network as a field of creativity, it is observed that numerous cities have begun to accept gastronomy as a creative industry that would contribute to their social, cultural, and economic development (Xiaomin, 2017). The following criteria must be met in order to be identified and awarded as a Creative City of Gastronomy by UNESCO Creative Cities Network (Creative Cities Brochure, 2018):

- Well-developed gastronomy culture that is characteristic of the urban center and/or region,

- Vibrant gastronomy community with numerous traditional restaurants and/or chefs,

- Endogenous ingredients used in traditional cooking,

- Local know-how, traditional culinary practices and methods of cooking that have survived industrial/technological advancement,

- Traditional food markets and traditional food industry,

- Tradition of hosting gastronomic festivals, awards, contests and other broadlytargeted means of recognition,

- Respect for the environment and promotion of sustainable local products,

- Nurturing of public appreciation, promotion of nutrition in educational institutions and inclusion of biodiversity conservation programs in cooking schools curricula.

Since the city of Popayan (Colombia) has first joined in gastronomy themed creative cities network in 2005, the number of cities within the network has reached 26 up to end of 2018 (https://en.unesco.org/creative-cities/). 
Comparative Content Analysis of the Websites

of Gastronomy Cities Rewarded by Unesco Creative Cities Network

Table 2. UNESCO Creative Cities Network, Gastronomy Cities

(Data source: adapted from https://en.unesco.org/creative-cities/)

\begin{tabular}{|c|c|c|c|}
\hline City & Year joined & Country & Language \\
\hline Popayán & 2005 & Colombia & Spanish \\
\hline Chengdu & 2010 & China & Chinese \\
\hline Östersund & 2010 & Sweden & Swedish \\
\hline Jeonju & 2012 & South Africa & Korean \\
\hline Zahlé & 2013 & Lebanon & Arabic \\
\hline Florianopolis & 2014 & Brasil & Spanish \\
\hline Shunde & 2014 & China & Chinese \\
\hline Tsuruoka & 2014 & Japan & Japanese \\
\hline Belém & 2015 & Brasil & Spanish \\
\hline Bergen & 2015 & Norway & Norwegian \\
\hline Burgos & 2015 & Spain & Spanish \\
\hline Denia & 2015 & Spain & Spanish \\
\hline Ensenada & 2015 & Mexico & Spanish \\
\hline Gaziantep & 2015 & Turkey & Turkish \\
\hline Parma & 2015 & Italy & Italian \\
\hline Phuket & 2015 & Tailand & Thai \\
\hline Rasht & 2015 & Iran & Farsi \\
\hline Tuscon & 2015 & USA & English \\
\hline Alba & 2017 & Italy & Italian \\
\hline Buenaventura & 2017 & Colombia & Spanish \\
\hline Cochabamba & 2017 & Bolivia & Spanish \\
\hline Hatay & 2017 & Turkey & Turkish \\
\hline Macao & 2017 & SAR* (China) & Chinese \\
\hline Panama & 2017 & Panama & Spanish \\
\hline Paraty & 2017 & Brasil & Spanish \\
\hline San Antonio & 2017 & USA & English \\
\hline
\end{tabular}

${ }^{*}$ A Special Administrative Region of People's Republic of China

\section{Promotion of Gastronomy Cities and the Internet}

The cities that consider gastronomy within the scope of creative industries, and as an important asset that accelerates social, cultural, and economic developments, would take a great opportunity to promote themselves to the world after joining UNESCO Creative Cities Network and becoming gastronomy cities. As such, gastronomy should be considered as the result of current political, social or economic needs. In this sense, such a cultural (gastronomic) heritage must be understood as an approach of understanding the past at present (Matlovičová \& Husarová 2017, p. 7). In this regard, the key links of the past with the present through the preserved tangible and intangible relics of the environment is the essence of heritage marketing. Heritage marketing have the ability to transcend time and allow the past to exist in the present. It also plays an important role in shaping the presence (Matlovičová \& Husarová 2017, p. 7). Consequently, the cities and regions can create and develop their image, increase their recognition, and promote their gastronomy identity on international level by utilizing internet technologies efficiently to increase tourism income of the local communities and the country and seize this opportunity.

It is known that many tourists seek to get more information about destinations that they are curious about or interested in tourism industry, which also includes gastronomy (Lee et al., 2006) and that they refer to different sources of information to make the right decision when it comes to choosing a destination (Ho et al., 2012). Sources and range of information influence the tourists' intentions to visit a destination (Dey \& Sarma, 2010). 
In this regard, it is necessary to consider the concept of branding and image. The image of the destination should be perceived as multidimensional concept consisting of fucntional, emotional, relational and strategic elements which together create a unique set of associations connected with the place in the minds of the public (Matlovičová \& Kormaníková 2014, p. 2). There are numerous studies about the ways the tourists use the internet as a source of information, and the ways the service providers utilize the internet to influence the decisions of the tourists (Araña et al., 2015; Buhalis \& Law, 2008; Ho et al., 2012; Litvin et al., 2008; Pan \& Fesenmaier, 2006; Xiang \& Gretzel, 2010).

While it is evident that the number of tourists who prefer to get more information about their travels through the internet and who make decisions according to these data has been increasing, it is also observed that the internet is used by the tourism industry as an excellent platform that can convey direct information about the product, service, cost, and time (Burger et al., 1997). Since they can both provide information and represent the cultural heritage of the destination online, the websites play a critical role in selection of the destination (Pan \& Fesenmaier, 2000) and they are frequently used by the potential tourists to obtain information and to develop a route (Lee, 2017; Ukpadi \& Karjaluoto, 2017; Tang-Taye \& Standing, 2016; Garau, 2014; Chiou et al., 2011).

The internet not only functions as a source of information for tourists, it is also a source of information for all other tourism enterprises, such as travel agencies, tour operators, and hotels (Özdemir, 2007). Thus, the internet, which has become a popular source of information and communication throughout the world, can host and convey all information about a destination. Therefore, it serves as a significant instrument of promotion for destinations. In order to promote a destination efficiently through websites, which play a significant role in direct promotion of a destination and creating an image and a brand (Sarı \& Kozak, 2005), the websites should be designed, and contents should be created in line with predetermined objectives and strategies (Palmer, 2002). The content and the form of presentation are very important to convince potential tourists (Law et al., 2004). Destination's image can be created and better positioned by developing up-to-date websites that are rich in information and visual contents (Chung et al., 2015). The destinations that are well-promoted in their websites can attract more tourists (Alcantara-Pilar et al., 2017; Garau, 2017; Horng \& Tsai, 2010; Han \& Mills, 2006).

The marketing of the destination also consists of the promotion of gastronomic values, and most destinations promote their dishes on their websites. Therefore, as suggested by Matlovičová and Pompura (2013, p. 130) it is possible to approach the food consumption and related activities as a means or an inevitable part of a tourist journey or as a target of a tourist journey when composing a tourist product and a marketing strategy. As such, destination marketing planners should consider the difference when promoting the gastronomic values in the destination websites.

\section{METHODOLOGY}

Content analysis method is used in this study, which is conducted to evaluate and analyze the official websites of gastronomy-themed cities that have been named 'Creative City of Gastronomy' within the scope of UNESCO Creative Cities Network. Content analysis is defined as an observational research method that used to systematically evaluate the real and symbolic content of all recorded forms of communication (Hall \& Valentin 2005). Content analysis, which is commonly used in social sciences, is regarded as a significant analysis technique that also includes web communications (Keskin \& Çilingir, 2010). This study comprises the websites of 26 cities that have met the criteria for UNESCO Creative Cities Network before 01.01.2019 and that have been announced in 
the official website of UNESCO as Gastronomy Cities. The official websites' URLs of 14 gastronomy cities were found in UNESCO's official website; the websites' URLs of 2 gastronomy cities were found via internet search engines. The remaining 10 cities do not have a 'Gastronomy City', 'Creative City', or 'Creative City of Gastronomy' themed website. In some tourism-themed websites of local governments, cities and/or countries, these cities are mentioned as gastronomy cities. However, it is observed that they do not have a solely gastronomy-themed website, and this was confirmed by local sources.

Thus, 10 cities (their websites) were excluded. On the other hand, since the gastronomy cities are located in different locations and countries, the official languages used in those websites are also different. Therefore, the research is limited to those gastronomy cities with websites in English language. With the assumption that the contents of the websites may eventually change in time since some information may be added, removed, or updated, the research is limited with the contents of websites published between 01.01.2019 and 13.01.2019. As a result, the written and visual contents of websites of 13 gastronomy cities were analyzed and compared.

The literature was reviewed in order to determine the criteria that will be used for content analysis. The studies regarding design, functionality, communication, interaction, information presentation, and contents of the websites were utilized (Baloğlu \& Pekcan, 2006; Zhou \& DeSantis, 2005; Tanrısevdi \& Duran, 2011; Baggio, 2003; Cox \& Dale, 2001; Gibson et al., 2003). In addition, in determining the evaluation criteria to be used for the analysis of gastronomy-themed websites within the scope of this study, specific evaluation criteria were created by using the expectations of UNESCO regarding the gastronomy culture of the city, which are listed in the guideline for candidate Gastronomy Cities. 4 academic members who are experts in their field were consulted to test the evaluation criteria in terms of contents and consistency, and the evaluation criteria took their final form after necessary corrections.

Table 3. The Websites with Analyzed Contents

\begin{tabular}{|c|c|}
\hline Gastronomy Cities & URLS \\
\hline Jeonju & http://unesco.jeonju.go.kr/eng/ \\
\hline Florianopolis & http://floripacreativecity.com/index.php?lang=en \\
\hline Tsuruoka & http://english.creative-tsuruoka.jp/ \\
\hline Belém & http://creativecity.belem.pa.gov.br/en/ \\
\hline Bergen & https://bergengastronomy.com/ \\
\hline Burgos & http://burgoslab.com/?lang=en \\
\hline Ensenada & https://www.ensenadacreativa.mx/ \\
\hline Gaziantep & http://www.gastroantep.com.tr/eng/ \\
\hline Parma & http://www.parmacityofgastronomy.it/en/ \\
\hline Tucson & http://tucson.cityofgastronomy.org/ \\
\hline Alba & http://www.albacityofgastronomy.it/ \\
\hline Hatay & http://hataygastronomi.com/en/home-2 \\
\hline Macao & http://www.gastronomy.gov.mo/\#home \\
\hline
\end{tabular}

Table 4. Evaluation Criteria for Websites of Gastronomy Cities

\footnotetext{
1. Design and Functionality (1 point assigned for each item present, total range 0-12)

1.1. Homepage and menus

1.2. Accessibility to Homepage

1.3. Multi language options ( 1 more language in addition to mother language)

1.4. Multi language options ( 2 or more languages in addition to mother language)

1.5. Mobile compatibility
} 
1.6. Full screen photograph on the homepage

1.7. Full screen video on the homepage

1.8. Sitemap

1.9. In-site search

1.10. In-site links

1.11. External links

1.12. Frequently asked questions

2. Communication and Interaction (1 point assigned for each item present, total range 0-10)

2.1. Online forum / blog

2.2. E-Bulletin membership

2.3. Communication form /e-mail

2.4. Contact informations

2.5. Media archive / press kit

2.6. Links to social media accounts

2.7. Facebook share button

2.8. Twitter share button

2.9. Other social media share buttons

2.10. Comment / like sections for contents

3. Destination Promotion (1 point assigned for each item present, total range 0-9)

3.1. Characteristics of the city

3.2. History of the city

3.3. Socio-cultural life

3.4. Transport

3.5. Climate

3.6. Accommodation

3.7. Tourist attractions

3.8. Travel and tour recommendations

3.9. Links to tourism enterprises

4. Gastronomy Promotion (1 point assigned for each item present, total range 0-18)

4.1. Gastronomy tradition

4.2. Local products

4.3. Sustainable agricultural practices

4.4. Local manufacturers (suppliers)

4.5. Food safety

4.6. Food variety

4.7. Beverage variety

4.8. Menu

4.9. Recipes

4.10. Culinary techniques and the utensils used

4.11. Gastronomy education

4.12. Gastronomy tours

4.13. Gastronomy evets (festivals, confereces, contests, etc.)

4.14. Local stakeholders (restaurants, workshops, ateliers, etc.)

4.15. Organization

4.16. Photo gallery

4.17. Video gallery

4.18. News

The websites within the scope of this study were visited, and checked in terms of whether each characteristic, statement, or content that were determined as evaluation 
criteria were included in writing and/or visually. Whether the websites meet the relevant criteria was evaluated by checking the website evaluation form as 1 (available) and o (not available) and each characteristic and dimension score were calculated in accordance with the scoring system of Gibson et al. (2003). The 'Evaluation Criteria for the Websites of Gastronomy Cities' which includes 4 dimensions and 49 sub-features as shown in Table 4 were used for content analysis.

\section{RESULTS AND DISCUSSIONS}

\section{Evaluation regarding Design and Functionality of Websites}

The websites are analyzed as to what extent they meet the criteria regarding the sub-features on design and functionality. The number and percentage of websites that have each feature are shown in Table 5. Accordingly, 12 websites have accessible homepages. 12 websites (92.31\%) have a second language in addition to its mother language; only one website offers three or more language options (7.69\%).

Table 5. The criteria in design and functionality dimension and the frequency of availability of these features on websites

\begin{tabular}{lcccc}
\hline \multirow{2}{*}{ Contents/Features } & \multicolumn{2}{c}{ available } & \multicolumn{2}{c}{ not available } \\
\cline { 2 - 5 } 1. Design and Functionality & $\mathbf{N}$ & $\mathbf{\%}$ & $\mathbf{N}$ & $\mathbf{\%}$ \\
\hline 1.1. Homepage and menus & & & & \\
\hline 1.2. Accessibility to Homepage & 12 & 92,31 & $\mathbf{1}$ & 7,69 \\
\hline 1.3. Multi language options (mother anguage +1 language) & 12 & 92,31 & $\mathbf{1}$ & 7,69 \\
\hline 1.4. Multi language options (mother language +2 or more languages) & $\mathbf{1}$ & 92,31 & $\mathbf{1}$ & 7,69 \\
\hline 1.5. Mobile compatibility & $\mathbf{1 0}$ & 76,99 & $\mathbf{1 1}$ & $\mathbf{8 4 , 6 2}$ \\
\hline 1.6. Full screen photograph on the homepage & 9 & 69,23 & 4 & $\mathbf{2 3}, 08$ \\
\hline 1.7. Full screen video on the homepage & 4 & 30,77 & 9 & 69,77 \\
\hline 1.8. Sitemap & $\mathbf{1}$ & 7,69 & $\mathbf{1 2}$ & 92,31 \\
\hline 1.9. In-site search & 4 & 30,77 & 9 & 69,23 \\
\hline 1.10. In-site links & $\mathbf{1}$ & 7,69 & $\mathbf{1 2}$ & 92,31 \\
\hline 1.11. External links & 8 & 61,54 & 5 & 38,46 \\
\hline 1.12. Frequently asked questions & $\mathbf{1}$ & 7,69 & $\mathbf{1 2}$ & 92,31 \\
\hline
\end{tabular}

The websites of 10 gastronomy cities (76.92\%) have mobile compatibility, and the written and visual contents are resized for devices such as telephones and tablets. Considering the fact that today, the internet is not only accessible through computers, but the mobile devices are also commonly used, mobile compatibility becomes a significant issue in web design. Only 4 websites (30.77\%) have in-site search option, which enables users to access information more easily and quickly.

Among all websites that preferred to have full screen visual images on their homepages, 9 websites included full screen photos, and 4 websites included full screen videos on their homepages. There are numerous local stakeholders and communities in these cities, which were awarded as gastronomy cities through the initiatives and projects of the government agencies or local governments. Nevertheless, there are websites (38.46\%) that do not provide external links. Similarly, $92.31 \%$ of these websites do not provide in-site links, as well. Only one website has a Frequently Asked Questions section.

\section{Evaluation of Websites' Power of Communication and Interaction}

When these websites are evaluated in terms of their communication and interaction characteristics, it is observed that only a few websites meet the criteria 
(Table 6). Contact information is available in 11 websites (84.62\%). While 2 websites offer direct communication through an online form, 2 websites do not have any sort of contact information. Only 2 (15.38\%) gastronomy city websites include a media archive or press kit section. One of the channels that media organizations and employees look to create their reports is websites. Having media contents in their websites can be very important for gastronomy cities that want to take part in written and visual media, and reach larger masses, however, it is observed that the contents of these websites are not sufficient. Social media is another instrument to reach larger masses and to strengthen communication with the users. Websites of 6 gastronomy cities (46.15\%) give links to their social media accounts. Their websites allow them to share the contents (photographs, videos, menus, events, news, etc.) of their websites in their social media accounts. 4 websites have a Facebook share button, 3 websites have a Twitter share button, and 2 websites have share buttons for other social media accounts. 3 websites allow their users to like or comment on their website content.

Table 6. The criteria in communication and interaction dimension and the frequency of availability of these features on websites

\begin{tabular}{lcccc}
\hline \multirow{2}{*}{ Contents/Features } & \multicolumn{2}{c}{ available } & \multicolumn{2}{c}{ not available } \\
\cline { 2 - 5 } & $\mathbf{N}$ & $\mathbf{\%}$ & $\mathbf{N}$ & $\mathbf{\%}$ \\
\hline 2. Communication and Interaction & & & & \\
\hline 2.1. Online forum / blog & $\mathbf{2}$ & 15,38 & $\mathbf{1 1}$ & 84,62 \\
\hline 2.2. E-Bulletin membership & $\mathbf{2}$ & 15,38 & 11 & 84,62 \\
\hline 2.3. Communication form /e-mail & $\mathbf{1 1}$ & 84,62 & 2 & 15,38 \\
\hline 2.4. Contact informations & 2 & 15,38 & 11 & 84,62 \\
\hline 2.5. Media archive / press kit & 6 & 46,15 & 7 & 53,85 \\
\hline 2.6. Links to social media accounts & 4 & 30,77 & 9 & 69,23 \\
\hline 2.7. Facebook share button & 3 & 23,08 & 10 & 76,92 \\
\hline 2.8. Twitter share button & 2 & 15,38 & 11 & 84,62 \\
\hline 2.9. Other social media share buttons & 3 & 23,08 & 10 & 76,92 \\
\hline 2.10. Comment / like sections for contents & & & & \\
\hline
\end{tabular}

Table 7. The contents about destination promotion and the frequency of availability on websites

\begin{tabular}{lcccc}
\hline \multirow{2}{*}{ Contents/Features } & \multicolumn{2}{c}{ available } & \multicolumn{2}{c}{ not available } \\
\cline { 2 - 5 } & $\mathbf{N}$ & $\mathbf{\%}$ & $\mathbf{N}$ & $\mathbf{\%}$ \\
\hline 3. Destination Promotion & & & & \\
\hline 3.1. Characteristics of the city & $\mathbf{1 1}$ & 84,62 & $\mathbf{2}$ & $\mathbf{1 5 , 3 8}$ \\
\hline 3.2. History of the city & 5 & 38,46 & 8 & 61,54 \\
\hline 3.3. Socio-cultural life & $\mathbf{2}$ & $\mathbf{1 5 , 3 8}$ & $\mathbf{1 1}$ & 84,62 \\
\hline 3.4. Transport & 3 & 23,08 & $\mathbf{1 0}$ & 76,92 \\
\hline 3.5. Climate & 2 & 15,38 & $\mathbf{1 1}$ & 84,62 \\
\hline 3.6. Accommodation & 1 & 7,69 & $\mathbf{1 2}$ & 92,31 \\
\hline 3.7. Tourist attractions & 4 & 30,77 & 9 & 69,23 \\
\hline 3.8. Travel and tour recommendations & 3 & 23,08 & 10 & 76,92 \\
\hline 3.9. Links to tourism enterprises & 3 & 23,08 & 10 & 76,92 \\
\hline
\end{tabular}

\section{Evaluation of Contents related to Destination Promotion}

The city's history, cultural and natural assets, and the local community are inseparable elements of gastronomy. Gastronomy culture, which emerges as creativity of the entire city and community, and awarded by UNESCO, allows cities to promote 
themselves in the international tourism market and to create an image. In this respect, it is essential that the websites of gastronomy cities should include information regarding promotion of other touristic assets of the destination along with other information about gastronomy. The cities are promoted in 11 out of 13 websites $(84.62 \%)$ and they include information about other characteristics of the cities. 2 websites do not have any information about the identity of the city. 5 websites include information about the history of the city, and only 2 websites include information about the socio-cultural life in the city. The websites offer limited information about transportation, climatic conditions, and accommodation in the city. 3 websites provide information about transportation, 2 websites provide information about the climate, and only 1 website provide information about accommodation. It is observed that 4 websites $(30.77 \%)$ feature contents about tourist attractions, and 3 websites (23.08\%) feature contents about travel and tour recommendations. 3 websites give external links to tourism enterprises independently from gastronomy communities and stakeholders. When the criteria for destination promotion are evaluated, it is observed that the majority of websites do not provide sufficient content about the destination promotion.

\section{Evaluation of Contents related to Gastronomy Promotion}

The contents of websites with their main themes being gastronomy, which are included within the scope of this study, were analyzed with regards to 18 sub-criteria determined under gastronomy promotion. Table 8 shows the number and the extent to which these websites meet each criteria or characteristic feature.

Table 8. The contents about gastronomy promotion and the frequency of availability on websites

\begin{tabular}{lcccc}
\hline \multirow{2}{*}{ Contents/Features } & \multicolumn{2}{c}{ available } & \multicolumn{2}{c}{ not available } \\
\cline { 2 - 5 } & $\mathbf{N}$ & $\mathbf{\%}$ & $\mathbf{N}$ & $\mathbf{\%}$ \\
\hline 4. Gastronomy Promotion & & & & \\
\hline 4.1. Gastronomy tradition & 11 & 84,62 & 2 & 15,38 \\
\hline 4.2. Local products & 10 & 76,92 & 3 & 23,08 \\
\hline 4.3. Sustainable agricultural practices & 2 & 15,38 & 11 & 84,62 \\
\hline 4.4. Local manufacturers (suppliers) & 6 & 46,15 & 7 & 53,85 \\
\hline 4.5. Food safety & 2 & 15,38 & 11 & 84,62 \\
\hline 4.6. Food variety & 8 & 61,54 & 5 & 38,46 \\
\hline 4.7. Beverage variety & 4 & 30,77 & 9 & 69,23 \\
\hline 4.8. Menu & 7 & 53,85 & 6 & 46,15 \\
\hline 4.9. Recipes & 2 & 15,38 & 11 & 84,62 \\
\hline 4.10. Culinary techniques and the utensils used & 1 & 7,69 & 12 & 92,31 \\
\hline 4.11. Gastronomy education & 5 & 38,46 & 8 & 61,54 \\
\hline 4.12. Gastronomy tours & 2 & 15,38 & 11 & 84,62 \\
\hline 4.13. Gastronomy evets (festivals, confereces, contests, etc.) & 9 & 69,23 & 4 & 30,77 \\
\hline 4.14. Local stakeholders (restaurants, workshops, atelier, etc.) & 7 & 53,85 & 6 & 46,15 \\
\hline 4.15. Organization & 6 & 46,15 & 7 & 53,85 \\
\hline 4.16. Photo gallery & 6 & 46,15 & 7 & 53,85 \\
\hline 4.17. Video gallery & 4 & 30,77 & 9 & 69,23 \\
\hline 4.18. News & 6 & 46,15 & 7 & 53,85 \\
\hline
\end{tabular}

11 websites $(84.62 \%)$ provide contents about a deep-rooted gastronomy tradition, which is one of UNESCO's criteria for gastronomy city candidates. Local products are significant assets to create a gastronomy tradition in a city. It is observed that the local products are promoted in 10 websites (76.92\%). However, only 6 websites (46.15\%) 
provide information about local manufacturers (suppliers). Only 2 websites provide contents about sustainable agriculture practices and food safety. The majority of websites (84.62\%) do not provide any information regarding these two aspects. It is observed that 8 websites address to promoted food variety and 4 websites address to promoted beverage variety. 7 websites share menus (53.85\%), but the recipes are not shared at the same percentage. Only 2 websites give recipes of limited amount of local foods.

Culinary techniques and the utensils used in kitchen have a significant role in creation of gastronomy culture and tradition. However, there is only 1 website that provides information about culinary techniques and the utensils used. 5 websites (38.46\%) provide information about gastronomy education and educational institutions, which are very important for protecting gastronomy culture, transferring these traditions to the next generations, and sustainability. 7 websites $(53.85 \%)$ provide promotional information about local stakeholders, such as restaurants, manufacturing facilities, factories, workshops, and farms. Considering the fact that gastronomy is a travel motivation that has an increasing trend in tourism industry, promoting gastronomythemed tours and events in websites could bring significant advantages for cities with regards to generating touristic demand. It is observed that 9 websites $(69.23 \%)$ publish contents about gastronomy events, such as festivals, conferences, contests, etc. However, only 2 websites (15.38\%) provide information about gastronomy tours within the city. All websites include more or less photos and/or videos; however, 6 websites (46.15\%) include contents under the name of photo gallery, and 4 websites (30.77\%) include contents under the name of video gallery. 6 websites provide gastronomy-themed news.

\section{Content Analysis Scores and Comparison of Websites}

In this content analysis, which was conducted under 4 dimensions and 49 criteria, the websites were given one point for each satisfied criterion, and dimension-based total scores of each website are calculated (Table 9). In Design and Functionality Dimension, which includes 12 criteria, the average score of the websites is calculated as 5.77 .

Table 9. Websites' content analysis scores

\begin{tabular}{|c|c|c|c|c|c|}
\hline & $\begin{array}{l}\text { Design } \\
\text { Funct. }\end{array}$ & $\begin{array}{l}\text { Comm. } \\
\text { Interact. }\end{array}$ & $\begin{array}{c}\text { Dest. } \\
\text { Promo. }\end{array}$ & $\begin{array}{l}\text { Gastro. } \\
\text { Promo. }\end{array}$ & Total Score \\
\hline Jeonju & 5 & 1 & 3 & 6 & 15 \\
\hline Florianópolis & 3 & 0 & $\mathrm{O}$ & 1 & 4 \\
\hline Tsuruoka & 4 & 1 & 3 & 10 & 18 \\
\hline Belém & 7 & $\mathrm{O}$ & 1 & 8 & 16 \\
\hline Bergen & 6 & 5 & 2 & 4 & 17 \\
\hline Burgos & 5 & 2 & 0 & 1 & 8 \\
\hline Ensenada & 4 & 4 & 1 & 3 & 12 \\
\hline Gaziantep & 4 & 1 & 2 & 11 & 18 \\
\hline Parma & 11 & 9 & 7 & 13 & 40 \\
\hline Tucson & 6 & 5 & 3 & 11 & 25 \\
\hline Alba & 5 & 2 & 1 & 7 & 15 \\
\hline Hatay & 8 & 6 & 4 & 13 & 31 \\
\hline Macao & 7 & 1 & 7 & 10 & 25 \\
\hline Mean score & $\mathbf{5 , 7 7}$ & $\mathbf{2 , 8 5}$ & 2,62 & 7,53 & $\mathbf{1 8 , 7 7}$ \\
\hline Range & 0-12 & 0-10 & o-9 & $0-18$ & $0-49$ \\
\hline
\end{tabular}


Considering the fact that the maximum score is 12 , it is observed that $48.1 \%$ of the criteria are satisfied, and thus, it is concluded that the websites are not able to meet the desired design and functionality features. When the scores of gastronomy cities are evaluated individually, it is observed that the top three cities with highest scores in design and functionality are Parma (11), Hatay (8), and Macao (7). It is also observed that the website of Parma, which satisfied 11 out of 12 criteria, has higher level of design and functionality than the other websites. There are 10 criteria under Communication and Interaction Dimension. The average score is calculated as 2.85 in this dimension and it is observed that $28.5 \%$ of the evaluation criteria are satisfied. This percentage, which is calculated as the lowest among all dimensions shows that websites of (many) gastronomy cities are insufficient in terms of communication and interaction features.

When the scores of the cities are analyzed, it is observed that the websites of Parma, Hatay, Tucson, and Bergen have more communication and interaction features than the others. Parma meets $90 \%$ of these criteria with its 9 points of dimension score, and it is followed by Hatay with 6 points, and Bergen and Tucson with 5 points each. It is observed that the gastronomy websites of Belem, which failed to meet any of these criteria, and Jeonju, Tsuruoka, Gaziantep, and Macao, which could only meet 1 criterion each, do not have any communication and interaction features.

The extent to which the contents of these websites give place to destination promotion independently from their gastronomy identities have been analyzed based on 9 criteria. The average destination promotion score calculated for 13 websites is 2.62, and it is far below the maximum score of 9. The gastronomy cities should effectively use their gastronomy city identities and their websites to promote their destinations in the international arena. However, the research findings indicate that the 13 websites could only meet $29.1 \%$ of destination promotion criteria, and that they do not give place to destination promotion adequately. The websites of Parma and Macao, which share the highest dimension score with 7 points, differ from the other websites in terms of destination promotion and provide sufficient information.

Parma and Macao could meet $77.8 \%$ of the criteria. In Gastronomy Promotion Dimension, which has the most criteria (18) among the dimensions, the average score of all websites is 7.53 . It may be concluded that this score, which represents $41.8 \%$ of possible maximum score 18 , is very low in general for websites, for which the main themes are gastronomy and gastronomy cities. Parma and Hatay, which have contents regarding 13 criteria on their websites, satisfy $72.2 \%$ of total evaluation criteria; Gaziantep and Tucson consist of 11 and satisfy $61.1 \%$ of these criteria; and Tsuruoka and Macao consist of 10 and satisfy $55.6 \%$ of these gastronomy promotion criteria.

According to total content analysis scores of websites, which are calculated independently from the dimensions, the total average score of 13 websites is 18.77 . It is also observed that $38.3 \%$ of all criteria are satisfied in this evaluation, where maximum score is 49 . When the websites of gastronomy cities are analyzed individually, Parma is ranked first among all websites and satisfied $81.6 \%$ of all content analysis evaluation criteria. Hatay is ranked second with a total of 31 points and its website satisfied $63.3 \%$ of all evaluation criteria. Tucson and Macao followed Parma and Hatay with 25 points each, and their websites satisfied $51 \%$ of all evaluation criteria. The cities with lowest scores are Florianopolis (4), Burgos (8) and Ensenada (12).

Co-Evaluation of Content Analysis Scores and Visibilities of Websites of Gastronomy Cities in Internet Search Engines

Within the context of this study, the visibility of websites of gastronomy cities in internet search engines is also checked and co-evaluated with the content analysis 
scores. The ratio of all internet searches between December 2017 and December 2018 are as follows: $92.21 \%$ Google, 2.39\% Bing, 2.13\% Yahoo, and 3.27\% other search engines (http://gs.statcounter.com/search-engine-market-share). Thus, it is decided to use only Google, and the names of the cities were typed together with the statement city of gastronomy and searched on 11.01.2019 and visibility scores (the number provided by Google) were logged (Chart 1). As shown in Figure 1, a two-dimensional matrix was created by search engine visibility scores ( $\mathrm{x}$ axis) and content analysis scores (y axis).

The average visibility of 13 cities is approximately 120.000, average score of content analysis is 18.77 , and these are marked on $\mathrm{x}$ and $\mathrm{y}$ axis respectively to create 4 sections (windows) on the matrix and to make evaluations.

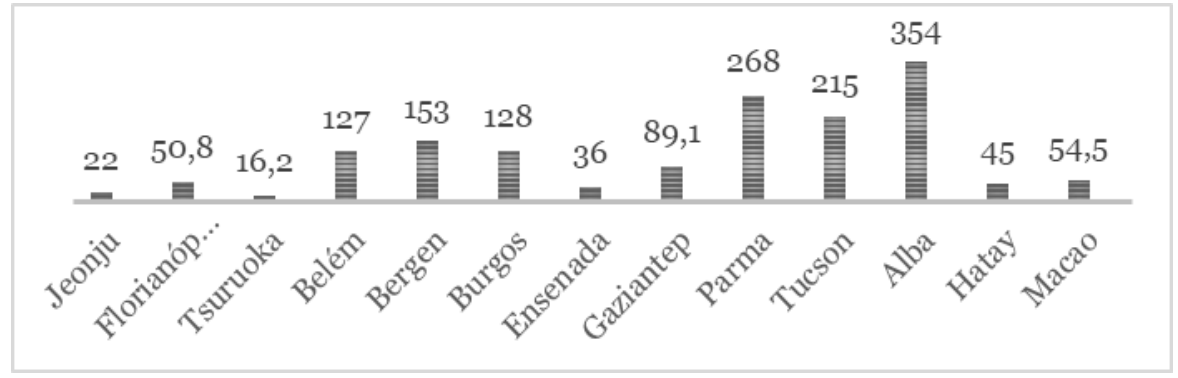

Chart 1. Search engine visibility of gastronomy cities (x1000)

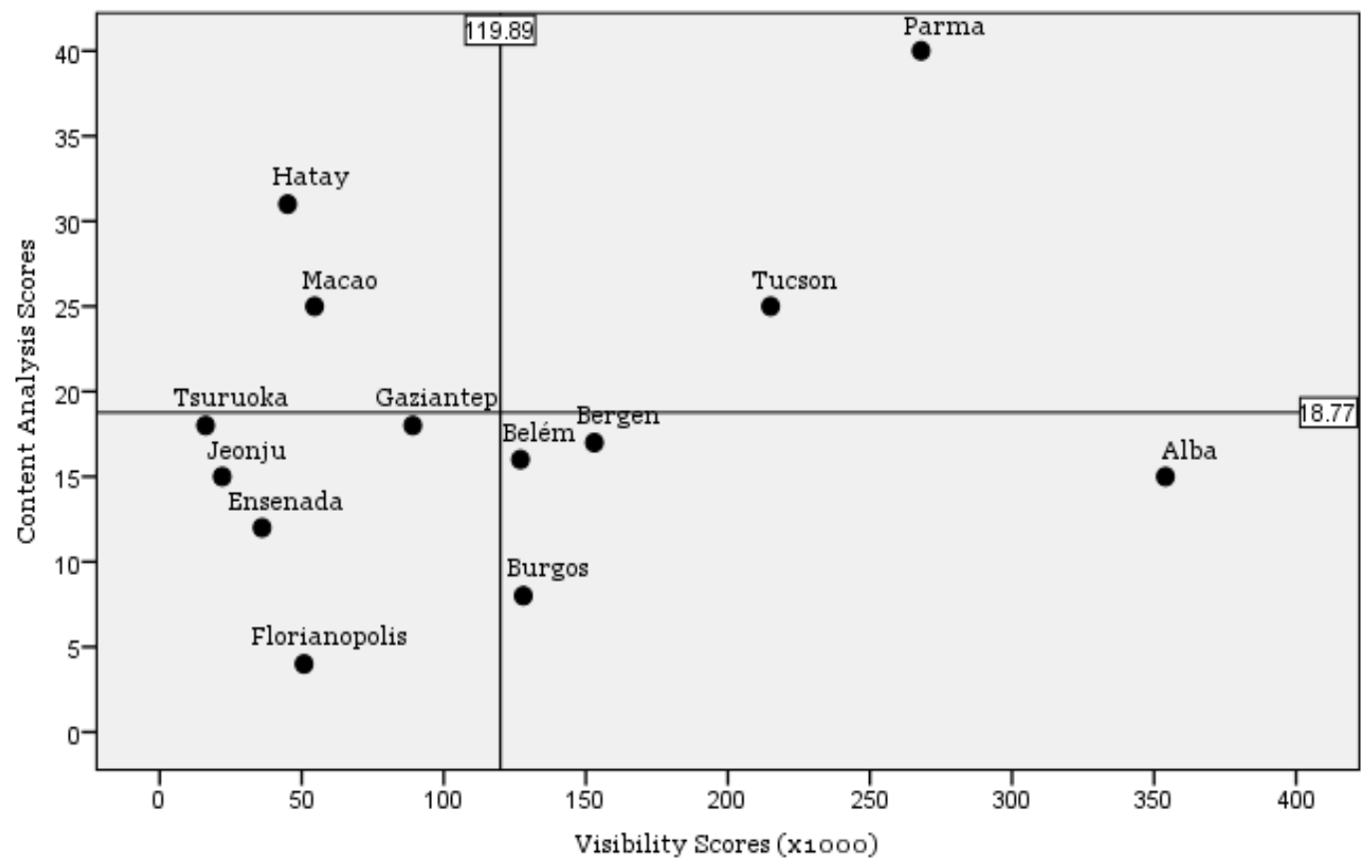

Figure 1. Co-Evaluation of Content Analysis

Scores and Visibilities of Websites of Gastronomy Cities in Internet Search Engines

Parma and Tucson are the two cities above the average in terms of both website content analysis score and visibility score, and they have found the ideal place on the 
matrix. Hatay and Macao have higher content analysis scores than the majority of other cities' websites with their website contents and the level of meeting the evaluation criteria. However, their internet search engine visibilities are quite low.

Alba, which has the highest visibility score, and Burgos, Belem, and Bergen, which also have above-average visibility scores, have higher number of search engine links. However, the content analysis scores of their websites are low, and they need to be increased. Jeonju, Tsuruoka, Gaziantep, Ensenada, and Florianopolis have lowest scores in terms of both visibility and website contents. It is observed that the content analysis scores of Tsuruoka and Gaziantep are very close to the average.

\section{CONCLUSION}

Gastronomy is one of the most important travel motivations and it is regarded as an increasing tourism trend; it provides economic, social, and cultural benefits for cities and local communities by contributing to the image, promotion, and marketing of various destinations. On the other hand, since UNESCO defined gastronomy as a field of creativity, and awarded the cities with deep-rooted gastronomy traditions as 'Creative City of Gastronomy', gastronomy has become a powerful instrument for promotion of the destinations. Gastronomy cities can promote themselves to the entire world through efficient use of the internet, which is one of the most significant sources that people look to get information about the destinations before they travel. The purpose of this study is to evaluate the websites of gastronomy cities through content analysis, and to reveal the level of competence of the website contents in terms of design, functionality, communication, interaction, destination promotion, and gastronomy promotion.

The results of content analysis indicate that the websites of the gastronomy cities that take place within UNESCO Creative Cities Network do not include sufficient amount of contents. According to the results of the research, the websites may be regarded as efficient in terms of design and functionality. However, in-site search option and frequently asked questions section should be included in order to make sure that the users can easily access the contents that they are interested. Only a few websites have these options. The websites were found ineffective in terms of communication and interaction features. Some websites do not even provide a contact information for users to communicate. The majority of websites do not offer communication and interaction instruments, such as communication forms, online forums, or e-bulletins. Only a few websites have contents for media communication, links to social media accounts, and the means to share contents in social media accounts. Gastronomy cities should strengthen their communication with the users who visit their websites.

It is observed that the websites do not efficiently promote their destinations independently from their gastronomy identity. In order to create a destination image, and to have a positive impact on destination choice processes of potential visitors, it is critical to promote all other attractions apart from the gastronomy culture. Thus, it should be considered that these websites are valuable platforms to promote a destination with its entirety. Contents related to the destination should be created and promoted on these websites in cooperation with local and national tourism offices.

When the contents regarding gastronomy promotion are analyzed, it is observed that the promotion level is relatively higher, however, not all websites include contents regarding sustainability, food safety, culinary techniques, utensils used, gastronomy tours, and gastronomy education. These contents, which distinguish gastronomy cities from the other cities, and which are related to the preconditions given by UNESCO to the candidate cities, should be emphasized more, and the gastronomy identity of the 
city should be promoted in all aspects. This study reveals that the readily available sources for promotion and marketing particularly within the context of gastronomy are not utilized in full capacity since the criteria specified by UNESCO are not effectively used in these websites. Considering the fact that these websites are visited by people, who would like to get more information about these cities within the creative cities network of UNESCO, it is clear that these websites should be used more effectively.

This study has some limitations. One of these limitations is that the content analysis of these websites is limited to the online content found between January 1, and January 13, 2019. Since the design and contents of these websites may change in time, the results of the analysis may reveal different results in future studies. Another limitation is that this study only comprises the websites published in English. Websites in different languages may be analyzed in other studies. A similar study may be conducted on social media accounts of gastronomy cities. Considering the fact that potential tourists can also create contents or comment on existing contents on social media, the gastronomy cities, social media contents and user contents can be analyzed together.

\section{REFERENCES}

Alcántara-Pilar, J. M., del Barrio-García, S., Crespo-Almendros, E., \& Porcu, L. (2017). Toward an understanding of online information processing in e-tourism: does national culture matter? Journal of Travel \& Tourism Marketing, 34(8), 1128-1142.

Araña, J. E., León, C. J., Carballo, M. M., \& Gil, S. M. (2015). Designing tourist information offices. The role of the human factor. Journal of Travel Research, 55(6), 764-773.

Atıf, Ö. (2018). Konaklama İşletmelerinin Web Sayfa Tasarımlarının Pazarlama Uygulamaları Açısından İncelenmesi: Eskişehir Ổneği. Journal of Turkish Tourism Research, 2(1), 15-26.

Baggio, R. (2003). A websites analysis of European tourism organizations. Anatolia, 14(2), 93-106.

Bakhshi, H., Hargreaves, I., \& Mateos-Garcia, J. (2013). A manifesto for the creative economy. London: National Endowment for Science, Technology and the Arts.

Baloglu, S., Pekcan, Y. A. (2006). The website design and Internet site marketing practices of upscale and luxury hotels in Turkey, Tourism Management, 27(1), 171-176.

Bayram, M., \& YAYLI, A. (2009). Otel web sitelerinin içerik analizi yöntemiyle değerlendirilmesi. Elektronik Sosyal Bilimler Dergisi, 8(27), 347-379.

Boden, M. A. (2009). Computer models of creativity. AI Magazine, 30(3), 23.

Boix R., Lazzeretti L., Hervàs J.L., De Miguel B. (2011). Creative clusters in Europe: a microdata approach, New challenges for European Regions and Urban Areas in a Globalized world; 1-33.

Buhalis, D., \& Law, R. (2008). Progress in information technology and tourism management: 20 years on and 10 years after the Internet: The state of eTourism research. Tourism Management, 29(4), 609-623.

Burger, F., Karoib, P., Pröll, B., Richtsfeld, R., Sighart, H. and Starck, H. (1997). TIS@WEB-database supported tourist information on the web. In A.M. Tjoa (Eds.) Information and Communication Technologies in Tourism, (pp.180-189). Wien: Springer-Werlag

Chiou, W.C., Lin, C.C. and Perng, C. (2011), A strategic website evaluation of travel agencies, Tourism Management, Vol.32No.6, pp.1463-1473.

Choi, S., Lehto, X. Y., \& Morrison, A. M. (2007). Destination image representation on the web: Content analysis of Macau travel related websites. Tourism Management, 28(1), 118-129.

Chung, N., Lee, H., Lee, S. J., \& Koo, C. (2015). The influence of tourism website on tourists' behavior to determine destination selection: A case study of creative economy in Korea. Technological Forecasting and Social Change, 96, 130-143.

Cox, J. ve Dale, B.G. (2002). Key Quality Factors in Web Site Design and Use, an Examination, International Journal of Quality ve Reliability Management, 19 (7), 862-888.

Dey, B., \& Sarma, M. K. (2010). Information source usage among motive-based segments of travelers to newly emerging tourist destinations, Tourism Management, 31(3), 341-344.

Escobar-Rodríguez, T., \& Carvajal-Trujillo, E. (2013). An evaluation of Spanish hotel websites: Informational vs. relational strategies. International Journal of Hospitality Management, 33, 228-239.

Garau, C. (2014). Smart paths for advanced management of cultural heritage. Regional Studies, Regional Science, 1(1), 286-293.

Garau, C. (2017). Emerging technologies and cultural tourism: Opportunities for a cultural urban tourism research agenda. In Tourism in the City (pp. 67-80). Springer, Cham. 
Gibson, R. K., Margolis, M., Resnick, D., \& Ward, S. J. (2003). Election Campaigning on the WWW in the USA and UK: A Comparative Analysis. Party Politics, 9(1), 47-75.

Hall, C ve Valentin, A, (2005) 'Content Analysis' Tourism Research Methods Integrating Theory with Practice (ed) Ritchie, B.W Burns, P. ve Palmer, C CABİ Cambridge.

Han, J. H., \& Mills, J. E. (2006). Zero acquaintance benchmarking at travel destination websites: what is the first impression that national tourism organizations try to make? International Journal of Tourism Research, 8(6), 405-430.

Hartley, J. (2005). Creative industries. Blackwell Publishing.

Hesmondhalgh, D. (2002). The cultural industries. London: Sage.

Ho, C., Lin, M., \& Chen, H. (2012). Web users' behavioral patterns of tourism information search: From online to offline. Tourism Management, 33(6), 1468-1482.

Horng, J. S., \& Tsai, C. T. S. (2010). Government websites for promoting East Asian culinary tourism: A crossnational analysis. Tourism management, 31(1), 74-85.

Ip, C., Law, R., \& Lee, H. A. (2012). The evaluation of hotel website functionality by fuzzy analytic hierarchy process. Journal of Travel \& Tourism Marketing, 29(3), 263-278.

Keskin, H., \& Çilingir, Z. (2010). Web Sitelerinin Globalizasyonu Üzerine Büyük Global Amerikan Markalarına Yönelik Bir İçerik Analizi Uygulaması. Eskişehir Osmangazi Üniversitesi İ̈BF Dergisi, 5(2), 51-66.

Kim, Y. H., Yuan, J., Goh, B. K., \& Antun, J. M. (2009). Web marketing in food tourism: A content analysis of web sites in West Texas. Journal of Culinary Science \& Technology, 7(1), 52-64.

Law, R., Leung, K. \& Wong, J. (2004). The Impact of The Internet on Travel Agencies. International Journal of Contemporary Hospitality Management, 16(2) 100-107.

Lee, C. B. (2017). Qualitative analysis of cultural tourism websites of municipalities in Taiwan. Information Technology for Development, 1-16.

Lee, G., Cai, L. \& O’Leary A. J. (2006). WWW. Branding States. US: An Analysis of Brand-building Elements in the US State Tourism Websites. Tourism Management, 27(5), 815-828.

Leung, D., Law, R., \& Lee, H. A. (2016). A modified model for hotel website functionality evaluation. Journal of travel \& tourism marketing, 33(9), 1268-1285.

Litvin, S. W., Goldsmith, R. E., \& Pan, B. (2008). Electronic word-of-mouth in hospitality and tourism management. Tourism Management, 29(3), 458-468.

Marinova E., \& Borza A. (2013). The Creative industries and New trends in the economic world. Economia, Seria Management, 16 (2); 327-332

Matlovičová K., \& Husárová M. (2017). Potential of the Heritage Marketing in Tourist Destinations Development. Cicva Castle Ruins Case Study (Heritage marketing a moznosti jeho vyuzitia pri rozvoji turistickej destinacie. Pripadova studia hradu Cicva). Folia Geographica, 59(1), 5-35.

Matlovičová K., \& Kormaníková J. (2014). City Brand-Image Associations Detection. Case Study of Prague. SGEM International Multidisciplinary Scientific Conferences on Social Sciences and Arts, SGEM 2014, Psychology \& Psychiatry, Sociology \& Healthcare, Education, Conference Proceedings, Volume II., Sociology and Healthcare, Albena, Bulgaria, 139-146.

Matlovičová K. , Pompura M. (2013). The Culinary Tourism in Slovakia Case Study of the Traditional Local Sheep's Milk Products in the regions of Orava and Liptov. GeoJournal of Tourism and Geosites, 12(2), 129-144.

Murphy J, Forrest EJ, Wotring CE, Brymer RA. (1996). Hotel management and marketing on the internet. Cornell Hotel and Restaurant Administration Quarterly, June, 70-82.

Özdemir, G. (2007). Destinasyon Pazarlamasında İnternetin Rolü, Journal of Yasar University ,2(8), 889-898.

Palmer, A. (2002). Destination branding and the web. In N. Morgan, A. Pritchard and R. Pride (Eds.) Destination Branding: Creating the Unique Destination Proposition, (pp. 186-197). Oxford: ButterworthHeinemann.

Pan, B., \& Fesenmaier, D. (2000). A typology of tourism-related web sites: Its theoretical background and implications. Information Technology \& Tourism, 3(3), 155-166.

Pan, B., \& Fesenmaier, D. R. (2006). Online information search: Vacation planning process. Annals of Tourism Research, 33(3), 809-832.

Roodhouse, S. (2006). The creative industries: definitions, quantification and practice. EISENBERG C. et al. (der.) içinde. Cultural industries: The British experience in international perspective. Berlin: Humboldt University, s. 13-32.

Salem, I. E. B., \& Čavlek, N. (2016). Evaluation of hotel website contents: existence-importance analysis. Journal of Hospitality and Tourism Technology, 7(4), 366-389.

Sarı, Y., \& Kozak, M. (2005). Turizm pazarlamasına internetin etkisi: destinasyon web siteleri için bir model önerisi. Akdeniz İktisadi ve İdari Bilimler Fakültesi Dergisi, 5(9), 248-271.

Schmidt S, Cantallops AS, dos Santos CP. (2008). The characteristics of hotel websites and their implications for website effectiveness. International Journal of Hospitality Management, 27(4): 504-516.

Tang-Taye, J. P., \& Standing, C. (2016). Website translation and destination image marketing: A case study of Reunion Island. Journal of hospitality \& tourism research, 40(5), 611-633.

Tanrisevdi, A., \& Duran, N. (2011). Comparative evaluation of the official destination websites from the perspective of customers. Journal of Hospitality Marketing \& Management, 20(7), 740-765. 
Taylor, C.F. (2006). 'Beyond Advocacy: Developing an Evidence Base for regional Creative Industry Strategies' in Cultural Trends, 15(57) pp. 3-18.

Ting, P. H., Wang, S. T., Bau, D. Y., \& Chiang, M. L. (2013). Website evaluation of the top 100 hotels using advanced content analysis and eMICA model. Cornell Hospitality Quarterly, 54(3), 284-293.

Ukpabi, D. C., \& Karjaluoto, H. (2017). Consumers' acceptance of information and communications technology in tourism: A review. Telematics and Informatics, 34(5), 618-644.

Xiang, Z., \& Gretzel, U. (2010). Role of social media in online travel information search. Tourism Management, 31(2), 179-188.

Xiaomin, C. (2017). City of Gastronomy of UNESCO Creative Cities Network: From International Criteria to Local Practice. Social Systems Studies, 55-67.

Zhou, Q., \& DeSantis, R. (2005). Usability issues in city tourism Web site design: a content analysis. In Professional Communication Conference, 2005. IPCC 2005. Proceedings. International (pp. 789-796). IEEE.

*** Alba, Creative City of Gastronomy, http://www.albacityofgastronomy.it/ accessed 01.01.2019.

*** Belém, Creative City of Gastronomy, http://creativecity.belem.pa.gov.br/en/ accessed 03.01.2019.

*** Bergen, Creative City of Gastronomy, https://bergengastronomy.com/ accessed 07.01.2019.

*** Burgos, Creative City of Gastronomy, http://burgoslab.com/?lang=en accessed 05.01.2019.

*** CCS (2013) Classifying and measuring the creative industries. London: Creative and Cultural Skills.

*** Creative Cities Network Catologue (2018). https://en.unesco.org/creative-cities/sites/creative-cities/files/ unesco_uccn_en_180530_final.pdf accessed 05.11.2018.

*** Creative Cities Brochure (2018), http://www.unesco.org/new/fileadmin/MULTIMEDIA/HQ/CLT/pdf/ Creative_cities_brochure_en.pdfaccessed 05.11.2018.

**** DCMS. (2001) Department of Culture Media and Sport, Creative industries mapping document https:// www.gov.uk/government/publications/creative-industries-mapping-documents-2001 accessed 12.12.2018.

*** Ensenada, Creative City of Gastronomy, https://www.ensenadacreativa.mx/ accessed 09.01.2019.

**** Florianopolis, Creative City, http://floripacreativecity.com/index.php?lang=en accessed 07.01.2019.

*** Gaziantep, Creative City of Gastronomy, http://www.gastroantep.com.tr/eng/ accessed 02.01.2019.

*** Global Stats (Search Engine Market Share Statistics) http://gs.statcounter.com/search-engine-market-share accessed 11.01.2019.

*** Hatay, Creative City of Gastronomy, http://hataygastronomi.com/en/home-2 accessed 02.01.2019.

*** Jeonju, Creative City of Gastronomy, http://unesco.jeonju.go.kr/eng/ accessed 02.01.2019.

*** Macao, Creative City of Gastronomy, http://www.gastronomy.gov.mo/\#home accessed 04.01.2019.

*** Parma, Creative City of Gastronomy, http://www.parmacityofgastronomy.it/en/ accessed 01.01.2019.

*** Tsuruoka, Creative City of Gastronomy, http://english.creative-tsuruoka.jp/ accessed 06.01.2019.

*** Tucson, Creative City of Gastronomy, http://tucson.cityofgastronomy.org/ accessed 08.01.2019.

*** UNCTAD (United Nations Conference on Trade and Development, 2008), https://unctad.org/en/Docs/ ditc20082cer_en.pdf accessed 04.11.2018.

https://en.unesco.org/creative-cities/ accessed 03.11.2018.

https://en.unesco.org/creative-cities/content/about-us accessed 05.11.2018.

https://en.unesco.org/creative-cities/content/why-creativity-why-cities accessed 05.11.2018.

https://en.unesco.org/creative-cities/creative-cities-map accessed 03.11.2018.

Submitted:

18.04.2019
Revised:

25.09.2019
Accepted and published online 27.09.2019 